\title{
ALPHA-HEMOGLOBIN REGULATES SYMPATHOADRENAL CELL METABOLISM TO MAINTAIN CATECHOLAMINERGIC PHENOTYPE
}

María T. Marcos-Almaraz ${ }^{*}$, José A. Rodríguez-Gómez ${ }^{*}$, José López-Barneo ${ }^{*}$, , and Alberto Pascual ${ }^{*}, \dagger$.

From Instituto de Biomedicina de Sevilla, Hospital Universitario Virgen del Rocío/ CSIC/Universidad de Sevilla, 41013 Seville, Spain*, and Centro de Investigación Biomédica en Red sobre Enfermedades Neurodegenerativas (CIBERNED), Spain ${ }^{\dagger}$.

Short title: $\alpha-\mathrm{Hb}$ expression in sympathoadrenal lineage

Address correspondence to: Alberto Pascual, Instituto de Biomedicina de Sevilla, Hospital Universitario Virgen del Rocío. Av. Manuel Siurot s/n. 41013-Seville, Spain. Phone: +34955923049; Fax:+34955923101; E-mail: apascual-ibis@us.es

Keywords: hemoglobin, oxidative stress, dopamine, tyrosine hydroxylase, sympathoadrenal lineage 
Discovery of hemoglobin A expression outside of the erythroid cell lineage suggests that oxygen transport is the main but not the unique function of adult hemoglobin chains in mammals. The contribution of hemoglobin A to antioxidant defenses has been proposed in the territories where it is expressed. Catecholaminergic cells relay on an active oxidative metabolism to accomplish their biological function but are exposed to strong oxidative stress due to metabolism of catecholaminergic transmitters. We show here that peripheral catecholaminegic cells express the alpha and not the beta hemoglobin A chains and that alpha-hemoglobin expression could modulate the antioxidant capabilities of these cells. We also show that alpha hemoglobin overexpression in PC12 cells leads to a selective increase of tyrosine hydroxylase synthesis and activity. This is achieved by means of a reorganization of antioxidant defenses, decreasing cytoplasmic glutathione peroxidase and superoxide dismutase and increasing mitochondrial peroxidase. Moreover, alpha hemoglobin induces a decrease in lipogenesis and increase in lipid degradation, situations that help saving NAD $(\mathrm{P}) \mathrm{H}$ and favor supply of acetyl-CoA to the Krebs cycle and production of cell's reducing equivalents. All these data point to a role of alpha hemoglobin as a regulator of catecholaminergic cell metabolism required for phenotype acquisition and maintenance. 


\section{INTRODUCTION}

The globin superfamily of proteins exists in the three life kingdoms [1]. Hemoglobins (Hbs), defined as hemoproteins containing five to eight $\alpha$-helices and presenting an invariant His at position $\mathrm{F} 8$-the proximal ligand to the heme iron-, can appear as tetrameric or monomeric forms. In vertebrates there are several $\mathrm{Hb}$ chains, with different cellular or systemic roles. The main erythrocyte $\mathrm{Hb}(\mathrm{HbA})$ is composed by two $\alpha$ and two $\beta$ chains. Erythroid cells also express the erythrocyte-associated factor (Eraf) that prevents $\alpha-\mathrm{Hb}$ precipitation before formation of functional heterotetramers with $\beta-\mathrm{Hb}[2]$. During ontogeny, several other $\mathrm{Hbs}$ are expressed to adjust their oxygen $\left(\mathrm{O}_{2}\right)$ and carbon dioxide affinities to the specific physiologic requirements. There are also monomeric forms of $\mathrm{Hb}$ expressed by connective tissue (cytoglobin; [3, 4]) and neurons (neuroglobin; [5]). The role of these globins is as yet uncertain but they are generally believed to play a protective role during hypoxic stress [6-8]. These two proteins are induced by physiologic hypoxia and their expression is decreased upon reoxygenation [8-10].

The common function of $\mathrm{Hbs}$ as vertebrate $\mathrm{O}_{2}$ carrier is a relatively recent adaptation during evolution, required to ensure correct delivery of $\mathrm{O}_{2}$ to all cells of the body by means of the vascular network. In addition to this classical role, $\mathrm{Hbs}$ can perform other cellular activities, including NO scavenging, intracellular oxygen transport, $\mathrm{O}_{2}$ sensing, hydrogen peroxide removal, and iron metabolism regulation (see for a review [11]).

Recent reports have detected $\mathrm{Hb}$ chains in non-erythroid cells. These include macrophages, alveolar cells, eye's lens, mesangial cells of the kidney, and several cell types of the central nervous system [12-16]. Putative roles for $\mathrm{Hb}$ chains in these new territories have been proposed, including antioxidant defense [16] and regulation of mitochondrial activity [12]. In brain, it is quite prominent the expression of both $\alpha$ and $\beta$ chains of $\mathrm{HbA}$ in dopaminergic neurons of substantia nigra, where it has been proposed to act as a modulator of genes involved in $\mathrm{O}_{2}$ homeostasis and oxidative phosphorylation [12]. Within the peripheral nervous system, catecholaminergic cells are generated during development from neural crest-derived sympathoadrenal precursors, which give rise to sympathetic neurons, chromaffin cells of the adrenal medulla (AM), and other paraganglia. Catecholaminergic cells release noradrenaline and adrenaline, among other neurotransmitters. Under certain conditions, catecholamines and their derivatives can be oxidized to form reactive intermediates as quinones and semiquinones [17], which has lead to suggest that such molecules could be involved in the pathogenesis of neurodegenerative diseases [18].

We show here that sympathoadrenal cells express exclusively the $\alpha$ (and not the $\beta$ ) chain of HbA. By using a cellular model of chromaffin cell (PC12 cells), we have confirmed these results, and investigated the putative roles of this protein in the normal physiology of sympathoadrenal cells. Unexpectedly, we have found that the molecular and functional expression of tyrosine hydroxylase $\mathrm{TH}$, the rate-limiting enzyme for the synthesis of catecholamines, strongly depend on the presence of heme-bound $\alpha-\mathrm{Hb}$. The increase of $\mathrm{TH}$ activity promotes the catecholaminergic phenotype of PC12 cells by up-regulating the levels of dopamine and noradrenaline. Our study suggests that $\alpha-\mathrm{Hb}$ induces a reorganization of cell metabolism that results in increased antioxidant cellular defense, a situation that increases TH mRNA and protein levels.

\section{EXPERIMENTAL}

\section{Animals}

Mice were maintained under 12:12 hour cycle of light with ad libitum access to food and water and genotyped according to the original references. Animal care and experimentation were done following the institutional animal care committee guidelines. Heterozygous $T H-E G F P$ transgenic mice and the corresponding wild-type littermates obtained form the GENSAT project [19] were used for $\mathrm{TH}+$ cell isolation. Three young adult mice (up to two months old) were sacrificed by sodium pentobarbital (i.p.) overdose to extract the superior cervical ganglions (SCG) and adrenal glands.

\section{Cell sorting}

AM cells were dispersed as described in [20]. SCG sympathetic cells were isolated by enzymatic treatment with trypsin-I (SIGMA) and collagenase-II (SIGMA) in PBS. TH-EGFP+ cells were 
separated by FACS flow cytometry (MoFlo, Cytomation) selecting only cells with high level of fluorescence.

\section{Cell culture and hypoxic treatments}

PC12, NIH-3T3, and MAH cells were grown in Dulbecco's modified Eagle's medium (GIBCO) supplemented with $5 \%$ fetal bovine serum (SIGMA), 10\% horse serum (GIBCO), 1\% L-glutamine (BioWhittaker) and $1 \%$ penicillin/streptomycin (BioWhittaker) in a $\mathrm{CO}_{2}$ incubator at $37^{\circ} \mathrm{C}$. Hypoxic conditions $\left(1 \% \mathrm{O}_{2}, 94 \% \mathrm{~N}_{2}\right.$, and $\left.5 \% \mathrm{CO}_{2}\right)$ were achieved in a humidified variable aerobic workstation (Invivo2 300; Ruskin). In all experiments, cells were plated at 30\%-50\% confluence to prevent the development of anaerobic conditions at $1 \% \mathrm{O}_{2}$.

\section{Plasmid constructions}

To construct a vector expressing both $\alpha$-globin (Hba-a2) and erythroid associated factor (Eraf) in mammalian cells, the EGFP sequence was removed from pIRES2-EGFP vector (Clontech) by BstXI/NotI digestion. BstXI end was blunted with T4 DNA polymerase (Promega). The Eraf cDNA containing plasmid (IMAGp998O0318184Q, ImaGenes) was digested with NotI/SmaI and ligated in the pIRES2 vector. The Hba-a2 cDNA (IRBPp993F0642D, ImaGenes) was isolated by EcoRI/XhoI digestion and cloned into pIRES2-Eraf vector digested with EcoRI/SalI. The resulting plasmid was pHba-IRES-Eraf. The same plasmid was mutated using the Quick change site-directed mutagenesis kit (Stratagene) to produce the $\mathrm{pHba}^{\mathrm{H} 88 \mathrm{R}}$-IRES-Eraf plasmid. Mutation incorporation into the plasmid DNA was verified by sequencing.

\section{Clone isolation}

To obtain clones, PC12 cells were either electroporated with $10 \mu \mathrm{g}$ of pHba-IRES-Eraf or $\mathrm{pHba}^{\mathrm{H} 88 \mathrm{R}}$ IRES-Eraf and cultured in presence of Neomycin $(400 \mu \mathrm{g} / \mathrm{ml})$. Individual clones were cultured independently. mRNA levels of Hba-a2 and Eraf were estimated by quantitative RT-PCR and the clones presenting similar expression levels were selected. Primers sequences are available under request. All of them were designed with the program Primer express (Applied BioSystems).

\section{RNA analysis}

mRNA was extracted from AMs and SCGs TH-EGFP+ cells following manufacturer protocol (Dynabeads, Invitrogen). RNA extraction from PC12 cells was done with TRIzol reagent following standard procedures (Trizol, Invitrogen). First strand cDNA was synthesized using the Superscript first strand synthesis system for RT-PCR (Invitrogen). Standard PCR amplifications of $\alpha-\mathrm{Hb}, \beta-\mathrm{Hb}$, and aminolevulinate delta- synthase 2 (Alas2) encoding genes were performed using specific primers whose sequences are available under request. Presence of Eraf in the cells was estimated by quantitative RT-PCR using the primers described before. Quantitative RT-PCR analysis was performed in an ABI Prism 7500 Sequence Detection System (Applied Biosystems) using SYBR Green PCR Master mix (Applied Biosystems) and the PCR conditions recommended by the manufacturer. Each sample was analyzed for cyclophilin to normalize for RNA input amounts. To normalize mRNA levels in all experiments, we calculated an average $\Delta$ cycle threshold of the control samples and processed all the samples in the experiment relative to this average cycle threshold. Primers were designed using the computer program Primer Express (Applied Biosystems) and their sequences are available under request. Melting curve analysis showed a single sharp peak with the expected Tm for all samples.

\section{Proteomic}

PC12 cells were fractionated, labeled and resolved into 2-DE as described [21] with minor differences. Briefly, $20 \mu \mathrm{g}$ of protein were used instead of $50 \mu \mathrm{g}$ for P15 analysis. Four experimental replicates were used in each experiment and differences were analyzed using Decyder software (GE healthcare). MALDI-MS/MS was performed as described [21]. 


\section{Western blot}

PC12 clones from a confluent culture on a $10 \mathrm{~cm}$ diameter dish, were washed with cold PBS, scrapcollected in $1 \mathrm{ml}$ of cold PBS, and centrifuged at $165 \mathrm{~g}$ for $5 \mathrm{~min}$ at $4{ }^{\circ} \mathrm{C}$. Whole-cell protein extract were prepared as described [20]. Protein concentration was measured using the Bradford method (Bio-Rad Protein Assay) and $5 \mu \mathrm{g}$ of each sample were resolved by SDS-PAGE (15\%). After electrophoresis, proteins were transferred into polyvinylidene difluoride (PVDF) membrane (HybondP, Amersham Biosciences), which was probed with 1:1000 anti-TH (SIGMA) and 1:1000 anti-RPL26 (SIGMA). Immunoreactive bands were developed with the ECL-Plus system (GE Healthcare) and visualized using a PhosphorImager (Typhoon 9400, GE Healthcare). Western blots were quantified using ImageQuant TL (GE Healthcare) software.

\section{Tyrosine hydroxylase (TH) activity rate}

The rate of tyrosine hydroxylation in PC12 cells was assayed in situ by measuring the accumulation of L-DOPA in the presence of the decarboxylase inhibitor NSD-1015 with modifications [22]. Cells were cultured in Krebs-Ringer HEPES buffer containing $125 \mathrm{mM} \mathrm{NaCl}, 4.8 \mathrm{mM} \mathrm{KCI}, 1.3 \mathrm{mM} \mathrm{CaCl}{ }_{2}$, $1.2 \mathrm{mM} \mathrm{MgSO}_{4}, 1.2 \mathrm{mM} \mathrm{KH}_{2} \mathrm{PO}_{4}, 5.6 \mathrm{mM}$ glucose, $25 \mathrm{mM}$ HEPES, $100 \mu \mathrm{M}$ EDTA, adjusted to $\mathrm{pH}$ 7.4 and was supplemented with $400 \mu \mathrm{M}$ NSD-1015. Samples were taken at 30, 60, 120 and 240 min after the beginning of the incubation and processed and analyzed by HPLC as for determination of monoamine levels (see below). For each condition the amount of L-DOPA per milligram of protein was plotted against time and the slope of the resulting line was determined by linear regression to give the rate of L-DOPA synthesis as nanogram of L-DOPA per milligram of protein per minute. The increase in the amount of L-DOPA accumulated with time using this method was linear, with an averaged R-squared value higher than 0.98 . For $\alpha-\mathrm{Hb}$ overexpressing cells estimation of the foldchange in TH activity rate was calculated as the ratio in L-DOPA production by these cells versus production by control cells.

\section{Measurement of dopamine and noradrenaline content}

PC12 cells were collected as for western-blot analysis and after centrifugation the pellets were resuspended on $150 \mu 1$ of chilled solution containing $0.1 \mathrm{M} \mathrm{HClO}_{4}, 0.02 \%$ EDTA and $1 \%$ ethanol. At this point the cellular extracts were centrifuged at maximal speed for $10 \mathrm{~min}$ at $4^{\circ} \mathrm{C}$. The resultant supernatants were filtered through a 30,000 Da MW exclusion membrane using Centrifugal Filter Devices (Millipore) by centrifugation at $13,200 \mathrm{~g}$ for $30 \mathrm{~min}$ at $4^{\circ} \mathrm{C}$. Filtered samples were injected onto HPLC (ALEXYS 100; Antec Leyden, Zoeterwoude, The Netherlands). Dopamine and noradrenaline levels were determined using a $3 \mu \mathrm{m}$ C-18 column (ALB-215; Antec Leyden), followed by electrochemical detection with a glassy carbon electrode and an in situ ISAAC reference electrode (Antec Leyden). Concentrations of dopamine and noradrenaline were expressed as nanogram per milligram of protein. Pelleted proteins were resuspended on $0.1 \mathrm{M} \mathrm{NaOH}$ for protein quantification by Bradford assay.

\section{Statistical analysis}

Unless otherwise specified, data are expressed as mean \pm S.E.M., with the number $(n)$ of experiments indicated. Statistical analysis were analyzed with either Student's $t$-test or one-way analysis of variance followed by Tukey's test. $p<0.05$ was considered statistically significant.

\section{RESULTS}

\section{Identification of $\alpha$ but not $\beta-\mathrm{Hb}$ transcripts in sympathoadrenal cells}

Recent studies have shown expression of hemoglobin chains outside erythroid cells [13-16]. In particular, $\alpha$ and $\beta$ chains of $\mathrm{Hb}$ are expressed by the dopaminergic cells of the substantia nigra [12]. To determine whether these observations can be made extensive to catecholaminergic cells in the peripheral nervous system, we have studied the presence of several chains of $\mathrm{Hb}$ in sympathetic neurons and chromaffin cells. To this end we have used transgenic mice (TH-EGFP) that selectively express EGFP under the control of tyrosine hydroxylase $(T h)$ gene promoter [19]. Primary cultures of AM or SCG cells from TH-EGFP mice allowed us a clear identification of TH+ cells (Figure 1A, left) 
and their highly purified separation by cell sorting (Figure 1A, right). RNA was extracted and the presence of chains of $\mathrm{HbA}$ was assayed by RT followed by standard PCR. TH+ cells from AM and SCG expressed $\alpha(H b a-a 2)$ but not $\beta-\mathrm{Hb}(H b b-b 1)$ chains (Figure 1B). These results were verified by qRT-PCR using a different set of primers (data not shown). RNA extracted from rat heart was used as a positive control. Due to the high blood content of this control sample, both $\mathrm{HbA}$ chains were identified as well as Aminolevulinate synthase 2 (Alas2), a gene specific of erythroid cells [23]. No expression of Alas 2 mRNA was detected in $\mathrm{TH}+$ cells, excluding the origin of $\alpha-\mathrm{Hb}$ mRNA amplification from an erythroid contamination of the TH+ sample isolated from SCG or AM (Figure 1B). In the TH- cells from AM and SCG the two HbA chains ( $\alpha$ and $\beta)$ as well as Alas 2 were detected, indicating the presence of erythroid cells in this population (Figure 1B).

The data described above prompted us to determine whether PC12 cells, a broadly used surrogate for chromaffin cells [24], also express $\alpha-\mathrm{Hb}$. Analysis of mRNA expression in PC12 cells confirmed that $\alpha-\mathrm{Hb}$ is the only $\mathrm{HbA}$ chain expressed by these cells (Figure 1C). The results were also confirmed by qRT-PCR. In addition, PC12 cells express the erythrocyte-associated protein (Eraf, also know as $\alpha-\mathrm{Hb}$ stabilizing protein $-\mathrm{AHSP}-$ ), a chaperon required for correct $\alpha$-Hb folding (data not shown). To demonstrate that $\alpha-\mathrm{Hb}$ amplification observed in PC12 cells was not due to any blood contamination in the culture medium, we cultured a fibroblast-derived cell line (NIH-3T3) using the same conditions and tested for the presence of $\alpha-\mathrm{Hb}$ mRNA. No amplification of $\alpha-$ or $\beta-\mathrm{Hb}$ mRNA was observed from NIH-3T3 cells using these conditions (Figure 1D). To test if $\alpha$-Hb mRNA expression is an exclusive characteristic of mature sympathoadrenal cells, we studied MAH cells, a cell-line originally immortalized from sympathoadrenal precursors [24]. Again no $\mathrm{Hb}$ expression was detected in MAH cells (Figure 1D), thus suggesting that $\alpha-\mathrm{Hb}$ mRNA expression is a characteristic of mature sympathoadrenal cells. Expression of $\alpha-\mathrm{Hb}$ chain is a rather selective phenomenon as no other $\mathrm{Hb}$ genes were detected by qRT-PCR in PC12 cells from a panel that included all fetal and adult alternative $\mathrm{Hb}$ chains (Supplemental Table 1). All these $\mathrm{Hb}$ chains were amplified in fetal and adult blood-containing tissues that were used as controls (data not shown).

\section{$\alpha-H b$ levels modulate antioxidant defense but do not alter oxygen sensing}

Several roles have been proposed to non-erythroid $\mathrm{HbA}$, including antioxidant functions, regulator of iron metabolism, and control of oxidative phosphorylation $[12,16]$. To investigate the function of $\alpha-$ $\mathrm{Hb}$ in peripheral catecholaminergic cells, we generated stably transfected PC12 cell lines overexpressing either wild-type $\alpha-\mathrm{Hb}$ or an inactive form of $\alpha-\mathrm{Hb}$ carrying an aminoacid change at the His responsible for coordinating the hemo prosthetic group (H88R, Figure 2A). To assure the correct folding of $\alpha-\mathrm{Hb}$, we used the same promoter to overexpress Eraf, a protein required for the correct folding of mature $\alpha-\mathrm{Hb}$ protein [2]. From the several cell lines generated, we choose two clones overexpressing high levels of wild-type or mutant forms of $\alpha-\mathrm{Hb}$ (Figure 2B, wt- $\alpha-\mathrm{Hb}$ and mut- $\alpha-H b$, respectively). Eraf expression correlated with $\alpha-H b$ in each case (Figure 2B). The doubling time of both clones was similar to that of the PC12 parental line and no morphological abnormalities were observed by overexpression of both proteins (data not shown).

We tested whether $\alpha-\mathrm{Hb}$ alters intracellular levels of oxygen, as one could argue that overexpression of an $\mathrm{O}_{2}$ binding protein might alter the intracellular $\mathrm{O}_{2}$ homeostasis, either by buffering molecular $\mathrm{O}_{2}$ or by modulating its transport to mitochondria. To test this hypothesis we measured Th and Vascular endothelial growth factor A (Vegfa) mRNA levels under normoxic and hypoxic conditions in the different clones generated. Th and $V E G F$ are well known oxygen-regulated genes that are induced by hypoxia via stabilization of hypoxia inducible factors (Hifs) [25-27]. Normoxic mRNA levels of Vegfa were unchanged by $\alpha$-Hb overexpression (Figure 3A, left panel). In contrast, the level of Th mRNA was clearly increased specifically in cells overexpressing wt- $\alpha-\mathrm{Hb}$ when compared with control or mut- $\alpha-\mathrm{Hb}$ overexpressing cell lines (Figure 3A, right panel). Moreover, the induction by hypoxia of both genes was conserved in all the clones assayed (Figure 3B). The induction of Th expression by hypoxia was smaller, but not significantly different, in the wt$\alpha-\mathrm{Hb}$ clone than in PC12 or mut- $\alpha-\mathrm{Hb}$ cell lines. This was due to the fact that, as indicated before (Figure $3 \mathrm{~A}$ ), Th mRNA levels in wt- $\alpha-\mathrm{Hb}$ cells were already higher than normal in normoxia and, 
therefore, the relative effect of hypoxia, although highly significant, was less manifested than in the two other cell types. These results indicate that, in contrast with what could happen in cells overexpressing $\mathrm{HbA}$ ( $\alpha$ and $\beta$ chains) [12], in PC12 cells $\alpha-\mathrm{Hb}$ overexpression does not seem to substantially modify intracellular $\mathrm{O}_{2}$ levels.

Th mRNA levels are known to be modulated by hypoxia, via Hif dependent transcriptional induction, and by reactive oxygen species (ROS) [28, 29]. It has also been described that $\mathrm{Hb}$ chains contribute to increase cellular antioxidant defenses [16, 30]. Hence, we tested whether $\alpha-\mathrm{Hb}$ overexpression modulates genes involved in ROS scavenging. We have studied three wellcharacterized antioxidant genes, glutathione peroxidase 1 (Gpxl), superoxide dismutase 1 (Sod1) and catalase (Cat). Gpxl and SOD1 expression levels were down regulated in wt- $\alpha-\mathrm{Hb}$ cell lines but did not change by mut- $\alpha-\mathrm{Hb}$ overexpression (Figure 4B). Catalase expression levels were not different when compared with control PC12 cells (Figure 4B). These results suggest that $\alpha$-Hb overexpression decreases cellular oxidant stress, thus leading to a decrease of enzymes involved in ROS metabolization.

\section{$\alpha$-Hb over-expression enhances catecholaminergic phenotype}

To carry out an unbiased analysis of cell proteins and metabolic pathways regulated by $\alpha-\mathrm{Hb}$, we have performed a proteomic comparison between PC12 cells, and the wt- $\alpha-\mathrm{Hb}$ and mut- $\alpha-\mathrm{Hb}$ cell lines. As previous reports have described a role of $\mathrm{Hb}$ in regulating mitochondrial and oxygen dependent genes [12], we have focused our analysis on soluble and mitochondrial subcellular fractions [21]. By using DIGE technology, we selected spots that changed their relative expression levels in wt $\alpha-\mathrm{Hb}$ cells in comparison with control and mut- $\alpha-\mathrm{Hb}$ PC12 cells (Figure 5). Overexpression of a mutated form of $\mathrm{Hb}$ unable to bind the hemo group produced significant changes in the PC12 soluble and mitochondrial proteome that were ascribed to non-specific cellular effects due to protein overexpression, and allowed for a better selection of specific cellular changes due to $\mathrm{wt}-\alpha-\mathrm{Hb}$ overexpression. Fingerprint analysis by MALDI-MS/MS revealed TH as one of the cytoplasmic proteins (S100 fraction) consistently up-regulated by $\alpha-\mathrm{Hb}$ overexpression (Supplemental Table 2). The most likely explanation for the presence of TH in the P15 fraction (see Supplemental Table 2) is the contamination of the mitochondrial-enriched fraction by this highly abundant protein normally confined to the cytosol. The findings of the unbiased global proteomic analysis and in excellent agreement with our observations at mRNA levels (Figure 3A), and confirm the absence of changes in the proteome related with $\mathrm{O}_{2}$ availability (Figure $3 \mathrm{~A}$ and $\mathrm{B}$ ). In addition to changes in TH levels, a cytoplasmic protein controlling lipogenesis (ATP citrate lyase) was decreased and a mitochondrial protein involved in lipid catabolism (ß-oxidation, long-chain acyl-CoA dehydrogenase precursor) was increased in wt $-\alpha-\mathrm{Hb}$ clone. This suggests that $\mathrm{wt}-\alpha-\mathrm{Hb}$ cells have a reorganization of cell metabolism oriented toward the increase of oxidative phosphorylation (reduction of lipogenesis and increase of acetyl CoA availability) and production of NAD $(\mathrm{P}) \mathrm{H}$ molecules. In agreement with this observation, a mitochondrial peroxidase involved in ROS scavenging in the mitochondrial electron transport chain was also increased in wt- $\alpha-\mathrm{Hb}$ clone [31] (Supplemental Table 2).

The increase of TH protein in the $\alpha$-Hb-expressing cells reported by the proteomic analysis was further confirmed by Western blot (Figure 6A). In addition, we estimated cell TH activity by inhibiting L-DOPA decarboxylase with NSD-1015 [22] and measuring the subsequent accumulation of L-DOPA. PC12 clones overexpressing wt- $\alpha-\mathrm{Hb}$ synthesized L-DOPA to a rate twice the ones measured in PC12 or mut- $\alpha-\mathrm{Hb}$ cells (Figure 6B). The increase in the rate of dopamine synthesis leads to a clear accumulation of dopamine and noradrenaline in $\mathrm{wt}-\alpha-\mathrm{Hb}$ cells, thus enhancing their catecholaminergic phenotype (Figure 6C).

\section{DISCUSSION}

During the last years, expression of $\mathrm{HbA}$ chains outside of the erythroid lineage has been reported [12-16]. These new data on $\mathrm{Hb}$ expression pattern have suggested that, apart from their central role in blood $\mathrm{O}_{2}$ transport, mammalian hemoglobins may accomplish several other fundamental cellular 
functions. In fact, analysis of $\mathrm{Hb}$ functions during evolution indicates that $\mathrm{O}_{2}$ transport must have been a very recent adaptation from its enzymatic and $\mathrm{O}_{2}$ sensing original tasks [11]. The presence of both $\alpha$ and $\beta \mathrm{HbA}$ chains in several cell types, including central neurons, have lead us to investigate the expression and functional role of these genes in the peripheral nervous system. We have focus our study on sympathoadrenal cells due to their catecholaminergic phenotype, a characteristic that is shared with some of the central neurons that express $\alpha$ and $\beta-\mathrm{Hb}$ mRNA, in particular with A9 and A10 nuclei [12]. In addition, we have a long-standing interest in the sympathoadrenal cell lineage that participates in mammalian acute oxygen sensing [32-34]. Surprisingly, we only detected $\alpha$, and no $\beta-$ $\mathrm{Hb}$ mRNA, in isolated sympathetic neurons or chromaffin cells (Figure 1). The expression $\alpha-\mathrm{Hb}$ independently from other $\mathrm{Hb}$ chains in these sympathoadrenal cells is, to our knowledge, the first report of exclusive expression of an adult mammalian $\mathrm{HbA}$ chain, in strong contrast with all the extra erythroid territories analyzed so far, where $\alpha$ and $\beta$ chains show coordinated expression [12-16]. Cytoglobin, neuroglobin and myoglobin are monomeric $\mathrm{Hb}$ chains expressed by different cell types, with cellular functions that differ from the classical erythrocyte-associated $\mathrm{O}_{2}$ transport performed by heteromeric $\mathrm{HbA}[3,5,35]$. In fishes, gene duplications have given rise to a new $\alpha-\mathrm{Hb}$ locus that produces a pH-insensitive $\alpha-\mathrm{Hb}$ that cooperate in $\mathrm{O}_{2}$ transport under the variable physiological conditions observed in water [36]. This adaptive strategy produces monomeric $\alpha-\mathrm{Hb}$ that complements the normal function of the tetrameric $\mathrm{HbA}$. Our results suggest that $\alpha-\mathrm{Hb}$ expression in the sympathoadrenal lineage can also be an adaptive specialization to favor phenotype specification. In mammals, expression of the $\alpha-\mathrm{Hb}$ chain requires an $\alpha-\mathrm{Hb}$-stabilizing protein (Eraf) for its optimal folding in erythrocytes [2]. In the absence of Eraf, precipitation of $\alpha-\mathrm{Hb}$ results in impairment of erythropoiesis and exacerbation of $\beta$-thalassemia phenotypes due to increase of reactive oxygen species [37]. The relatively high level of expression of Eraf mRNA observed in PC12 cells (in conjunction with $\alpha-\mathrm{Hb}$ ) (Figures 1 and 2) suggests a requirement for this protein in the correct folding of $\alpha-\mathrm{Hb}$ in sympathoadrenal cells and supports the function of $\alpha-\mathrm{Hb}$ as a monomeric protein in these cells. Expression of both $\alpha-\mathrm{Hb}$ and Eraf in sympathoadrenal tissue was inferred in this study by estimating their mRNA levels. Future experimental work must be done to determine the expression of these proteins and their distribution in sympathoadrenal cells.

Recent work has provided some cues about $\mathrm{HbA}$ function in central dopaminergic neurons using a mouse dopaminergic cell line (MN9D) where $\alpha$ and $\beta$ chains were stably overexpressed [12]. These results point to a role of $\mathrm{HbA}$ in regulating $\mathrm{O}_{2}$ homeostasis, mitochondrial function and oxidative defenses. We have followed a similar approach in PC12 cells, a well-established model of chromaffin cells [38], and stably overexpressed $\alpha-\mathrm{Hb}$ and its chaperon Eraf, to prevent any deregulation due to increased oxidative stress associated with unbalanced expression of both proteins [37] (Figure 2). In addition, we have generated a cell line that expresses a mutated form of $\alpha-\mathrm{Hb}$ unable to bind hemo, to discard any generalized or unselective effect due to the non-specific overexpression of proteins. However, the physiological implications of the present work are mainly based in overexpression experiments and therefore their significance is limited. Additional experiments, including loss of function analysis, are required to support a role for $\alpha-\mathrm{Hb}$ in sympathoadrenal cell redox regulation.

Analysis of the mRNA levels of $\mathrm{O}_{2}$-sensitive genes revealed that, although in cells with $\alpha-\mathrm{Hb}$ over-expression the Th mRNA level is increased, this does not significantly alter the response to hypoxia in PC12 (Figure 3). This finding contrast with the up-regulation of several Hif targets observed after overexpression of $\alpha$ and $\beta \mathrm{HbA}$ chains in MN9D cells [12]. In addition, our proteomic analyses have revealed specific pathways associated with $\alpha-\mathrm{Hb}$ overexpression (Supplemental Table 2). $\alpha-\mathrm{Hb}$ modulates enzymes involved in lipid/oxidative metabolism. Particularly ATP-citrate lyase, involved in the cytoplasmic generation of acetyl-CoA -the initial precursor of fatty acid biosynthesis; the long-chain acyl-CoA dehydrogenase precursor, involved in fatty acid oxidation; and peroxiredoxin 6 , that protects against intramitochondrial oxidative stress generated by the electron transport chain [31,39]. Overall, our unbiased proteomic study points to a metabolic reorganization associated with an increased utilization of acetyl-CoA by Krebs cycle, due to a decrease in lipogenesis and an increase in $\beta$-oxidation. This adaptation should lead to a cellular increase in NAD(P)H levels (see Figure 7). 
The fact that $\alpha-\mathrm{Hb}$ overexpression induces a clear down regulation of Gpxl and SOD1 mRNAs (Figure 4) suggests that $\alpha-\mathrm{Hb}$ may have a role in the scavenging of hydrogen peroxide and preventing anion superoxide formation [16,30,40-43]. Recent papers have shown that in the presence of reduced pyridine nucleotides $\mathrm{Hb}$ chains can catalyze hydrogen peroxide removal at a significant rate in erythrocytes, being this activity stronger than that of the glutathione peroxidase-glutathione reductase system $[41,42]$. In addition, the heme group of $\alpha-\mathrm{Hb}$ could act as an electron sink, as suggested for the succinate dehydrogenase enzyme where the heme group does not contribute to the electron transport but prevents electron leakage $[40,43]$. These "peroxidase" and electron binding activities of overexpressed $\alpha-\mathrm{Hb}$ could release pressure over the Gpx1 and SOD1 scavenging enzymes and allow for their down-regulation. In this scenario, $\alpha$-Hb should then reinforce antioxidant cellular defenses and decrease the levels of ROS (see Figure 7). In addition to its direct control by the $\mathrm{O}_{2}$-sensitive Hif system, Th mRNA is also regulated by cellular ROS and treatment of cells with hydrogen peroxide leads to inhibition of Th mRNA expression [28]. Using several experimental approaches, we have shown that $\alpha-\mathrm{Hb}$ overexpression produces a robust up-regulation of tyrosine hydroxylase at the mRNA and protein levels (Figures 3,6A and 7; and Supplemental Table 2), which results in a clear increase of TH enzymatic activity (Figure 6B). However, the expression of other $\mathrm{O}_{2^{-}}$ regulated genes, like $V E G F$, was not affected by $\alpha-\mathrm{Hb}$ overexpression (Figure 3 and Supplemental Table 2). As a working model (Figure 7), we propose a scenario where $\alpha-\mathrm{Hb}$ mediates the decrease in cellular hydrogen peroxide levels, leading to a reorganization of the cellular antioxidant defenses (Figure 7, line 1), an optimization of cell metabolism with increased energy production and NADH synthesis (Figure 7, line 2), and promotion of the catecholaminergic (TH-enriched) cell phenotype (Figure 7, line 3). In this regard, the analysis of the cellular catecholamine profiles has revealed that, in the presence of $\alpha-\mathrm{Hb}$, the levels of both dopamine and noradrenaline are augmented when compared with control cells (Figure 6C). Therefore, $\alpha-\mathrm{Hb}$ may play a role in sympathetic cells allowing for increased production of catecholamines without the deleterious effect associated with their strong oxidative capabilities [17]. It is important to note that $\alpha-\mathrm{Hb}$ expression is associated with mature sympathoadrenal cells and that a cell line immortalized from sympathoadrenal precursors (MAH) does not express this protein (Figure 1D).

In conclusion, we report here that catecholaminergic cells of the sympathoadrenal lineage express the $\alpha-\mathrm{Hb}$ chain of $\mathrm{HbA}$, and that the expression of this protein is related with a metabolic specification that facilitates regulation of antioxidant defenses and the manifestation of the catecholaminergic cell phenotype. It could be that, besides in the peripheral nervous system, $\alpha-\mathrm{Hb}$ plays similar roles in central catecholaminergic neurons in the substantia nigra or the locus coeruleus affected in Parkinson's disease. Our current report should stimulate further studies required to fully understand the complex interactions between cellular ROS metabolism, catecholamine synthesis and storage, and cell survival; as well as the participation of $\mathrm{Hb}$ in the normal physiology or even the pathologies associated with these processes.

\section{ACKNOWLEDGMENTS}

The TH-EGFP mouse was obtained from the Gene Expression Nervous System Atlas (GENSAT) Project, NINDS Contracts N01NS02331 \& HHSN271200723701C to The Rockefeller University (New York, NY). We wish to thank A. Romero, R. Gómez, and L. Gao for advice and technical assistance in some experiments.

\section{FUNDING}

The work was funded by the Marcelino Botín Foundation, the Spanish Ministry of Science and Education, and the Andalusian Government. CIBERNED is funded by the Instituto de Salud Carlos III. Support from the Spanish Ministry of Science and Education for M.T.M.A. ("FPI" predoctoral fellowship) is also acknowledged.

\section{AUTHOR CONTRIBUTION}


M.T. Marcos-Almaraz performed the majority of the experiments; J. A. Rodriguez-Gomez designed and performed HPLC analysis; and J. Lopez-Barneo and A. Pascual designed and interpreted the results and wrote the manuscript.

\section{REFERENCES}

1 Vinogradov, S. N., Hoogewijs, D., Bailly, X., Arredondo-Peter, R., Gough, J., Dewilde, S., Moens, L. and Vanfleteren, J. R. (2006) A phylogenomic profile of globins. BMC Evol Biol. 6, 31

2 Kihm, A. J., Kong, Y., Hong, W., Russell, J. E., Rouda, S., Adachi, K., Simon, M. C., Blobel, G. A. and Weiss, M. J. (2002) An abundant erythroid protein that stabilizes free alpha-haemoglobin. Nature. 417, 758-763

3 Burmester, T., Ebner, B., Weich, B. and Hankeln, T. (2002) Cytoglobin: a novel globin type ubiquitously expressed in vertebrate tissues. Mol Biol Evol. 19, 416-421

4 Trent, J. T., 3rd and Hargrove, M. S. (2002) A ubiquitously expressed human hexacoordinate hemoglobin. J Biol Chem. 277, 19538-19545

5 Burmester, T., Weich, B., Reinhardt, S. and Hankeln, T. (2000) A vertebrate globin expressed in the brain. Nature. 407, 520-523

6 Brunori, M. and Vallone, B. (2007) Neuroglobin, seven years after. Cell Mol Life Sci. 64, 1259-1268

7 Fordel, E., Thijs, L., Martinet, W., Lenjou, M., Laufs, T., Van Bockstaele, D., Moens, L. and Dewilde, S. (2006) Neuroglobin and cytoglobin overexpression protects human SHSY5Y neuroblastoma cells against oxidative stress-induced cell death. Neurosci Lett. 410, 146-151

8 Li, D., Chen, X. Q., Li, W. J., Yang, Y. H., Wang, J. Z. and Yu, A. C. (2007) Cytoglobin up-regulated by hydrogen peroxide plays a protective role in oxidative stress. Neurochem Res. 32, 1375-1380

9 Fordel, E., Thijs, L., Martinet, W., Schrijvers, D., Moens, L. and Dewilde, S. (2007) Anoxia or oxygen and glucose deprivation in SH-SY5Y cells: a step closer to the unraveling of neuroglobin and cytoglobin functions. Gene. 398, 114-122

10 Sun, Y., Jin, K., Mao, X. O., Zhu, Y. and Greenberg, D. A. (2001) Neuroglobin is upregulated by and protects neurons from hypoxic-ischemic injury. Proc Natl Acad Sci U S A. 98, 15306-15311

11 Vinogradov, S. N. and Moens, L. (2008) Diversity of globin function: enzymatic, transport, storage, and sensing. J Biol Chem. 283, 8773-8777

12 Biagioli, M., Pinto, M., Cesselli, D., Zaninello, M., Lazarevic, D., Roncaglia, P., Simone, R., Vlachouli, C., Plessy, C., Bertin, N., Beltrami, A., Kobayashi, K., Gallo, V., Santoro, C., Ferrer, I., Rivella, S., Beltrami, C. A., Carninci, P., Raviola, E. and Gustincich, S. (2009) Unexpected expression of alpha- and beta-globin in mesencephalic dopaminergic neurons and glial cells. Proc Natl Acad Sci U S A. 106, 15454-15459

13 Dugas, J. C., Tai, Y. C., Speed, T. P., Ngai, J. and Barres, B. A. (2006) Functional genomic analysis of oligodendrocyte differentiation. J Neurosci. 26, 10967-10983

14 Liu, L., Zeng, M. and Stamler, J. S. (1999) Hemoglobin induction in mouse macrophages. Proc Natl Acad Sci U S A. 96, 6643-6647

15 Newton, D. A., Rao, K. M., Dluhy, R. A. and Baatz, J. E. (2006) Hemoglobin is expressed by alveolar epithelial cells. J Biol Chem. 281, 5668-5676

16 Nishi, H., Inagi, R., Kato, H., Tanemoto, M., Kojima, I., Son, D., Fujita, T. and Nangaku, M. (2008) Hemoglobin is expressed by mesangial cells and reduces oxidant stress. J Am Soc Nephrol. 19, 1500-1508 
17 Jacintho, J. D. and Kovacic, P. (2003) Neurotransmission and neurotoxicity by nitric oxide, catecholamines, and glutamate: unifying themes of reactive oxygen species and electron transfer. Curr Med Chem. 10, 2693-2703

18 Chinta, S. J. and Andersen, J. K. (2008) Redox imbalance in Parkinson's disease. Biochim Biophys Acta. 1780, 1362-1367

19 Gong, S., Zheng, C., Doughty, M. L., Losos, K., Didkovsky, N., Schambra, U. B., Nowak, N. J., Joyner, A., Leblanc, G., Hatten, M. E. and Heintz, N. (2003) A gene expression atlas of the central nervous system based on bacterial artificial chromosomes. Nature. 425, 917-925

20 Echevarria, M., Munoz-Cabello, A. M., Sanchez-Silva, R., Toledo-Aral, J. J. and Lopez-Barneo, J. (2007) Development of cytosolic hypoxia and hypoxia-inducible factor stabilization are facilitated by aquaporin-1 expression. J Biol Chem. 282, 30207-30215

21 Pascual, A., Romero-Ruiz, A. and Lopez-Barneo, J. (2009) Differential proteomic analysis of adrenal gland during postnatal development. Proteomics. 9, 2946-2954

22 McCullough, L. A. and Westfall, T. C. (1995) Neuropeptide Y inhibits depolarizationstimulated catecholamine synthesis in rat pheochromocytoma cells. Eur J Pharmacol. 287, 271-277

23 Munakata, H., Yamagami, T., Nagai, T., Yamamoto, M. and Hayashi, N. (1993) Purification and structure of rat erythroid-specific delta-aminolevulinate synthase. J Biochem. 114, 103-111

24 Vandenbergh, D. J., Mori, N. and Anderson, D. J. (1991) Co-expression of multiple neurotransmitter enzyme genes in normal and immortalized sympathoadrenal progenitor cells. Dev Biol. 148, 10-22

25 Czyzyk-Krzeska, M. F., Furnari, B. A., Lawson, E. E. and Millhorn, D. E. (1994) Hypoxia increases rate of transcription and stability of tyrosine hydroxylase mRNA in pheochromocytoma (PC12) cells. The Journal of biological chemistry. 269, 760-764

26 Liu, L. and Simon, M. C. (2004) Regulation of transcription and translation by hypoxia. Cancer Biol Ther. 3, 492-497

27 Semenza, G. L., Shimoda, L. A. and Prabhakar, N. R. (2006) Regulation of gene expression by HIF-1. Novartis Found Symp. 272, 2-8; discussion 8-14, 33-16

28 Kroll, S. L. and Czyzyk-Krzeska, M. F. (1998) Role of H2O2 and heme-containing $\mathrm{O} 2$ sensors in hypoxic regulation of tyrosine hydroxylase gene expression. Am J Physiol. 274, C167-174

29 Semenza, G. L. (2009) Regulation of oxygen homeostasis by hypoxia-inducible factor 1. Physiology (Bethesda). 24, 97-106

30 Goldstein, S. and Samuni, A. (2005) Intra- and intermolecular oxidation of oxymyoglobin and oxyhemoglobin induced by hydroxyl and carbonate radicals. Free Radic Biol Med. 39, 511-519

31 Drechsel, D. A. and Patel, M. (2010) Respiration-dependent $\mathrm{H} 2 \mathrm{O} 2$ removal in brain mitochondria via the thioredoxin/peroxiredoxin system. The Journal of biological chemistry. 285, 27850-27858

32 Garcia-Fernandez, M., Mejias, R. and Lopez-Barneo, J. (2007) Developmental changes of chromaffin cell secretory response to hypoxia studied in thin adrenal slices. Pflugers Arch. 454, 93-100

33 Lopez-Barneo, J., Pardal, R. and Ortega-Saenz, P. (2001) Cellular mechanism of oxygen sensing. Annu Rev Physiol. 63, 259-287

34 Ortega-Saenz, P., Pascual, A., Gomez-Diaz, R. and Lopez-Barneo, J. (2006) Acute oxygen sensing in heme oxygenase-2 null mice. The Journal of general physiology. 128, 405411 
35 Wittenberg, B. A. and Wittenberg, J. B. (1989) Transport of oxygen in muscle. Annu Rev Physiol. 51, 857-878

36 Bonaventura, C., Godette, G., Stevens, R., Brenowitz, M. and Henkens, R. (2005) Overproduction of alpha chains provides a proton-insensitive component to the bluefish hemoglobin system. The Journal of biological chemistry. 280, 40509-40514

37 Kong, Y., Zhou, S., Kihm, A. J., Katein, A. M., Yu, X., Gell, D. A., Mackay, J. P., Adachi, K., Foster-Brown, L., Louden, C. S., Gow, A. J. and Weiss, M. J. (2004) Loss of alpha-hemoglobin-stabilizing protein impairs erythropoiesis and exacerbates betathalassemia. J Clin Invest. 114, 1457-1466

38 Greene, L. A. and Tischler, A. S. (1976) Establishment of a noradrenergic clonal line of rat adrenal pheochromocytoma cells which respond to nerve growth factor. Proc Natl Acad Sci U S A. 73, 2424-2428

39 Eismann, T., Huber, N., Shin, T., Kuboki, S., Galloway, E., Wyder, M., Edwards, M. J., Greis, K. D., Shertzer, H. G., Fisher, A. B. and Lentsch, A. B. (2009) Peroxiredoxin-6 protects against mitochondrial dysfunction and liver injury during ischemia-reperfusion in mice. Am J Physiol Gastrointest Liver Physiol. 296, G266-274

40 Hederstedt, L. (2003) Structural biology. Complex II is complex too. Science. 299, $671-672$

41 Masuoka, N., Kodama, H., Abe, T., Wang, D. H. and Nakano, T. (2003) Characterization of hydrogen peroxide removal reaction by hemoglobin in the presence of reduced pyridine nucleotides. Biochimica et biophysica acta. 1637, 46-54

42 Masuoka, N., Wakimoto, M., Ohta, J., Ishii, K. and Nakano, T. (1997) Characterization of hydrogen peroxide removal activities in mouse hemolysates: catalase activity and hydrogen peroxide removal activity by hemoglobin. Biochim Biophys Acta. 1361, 131-137

43 Yankovskaya, V., Horsefield, R., Tornroth, S., Luna-Chavez, C., Miyoshi, H., Leger, C., Byrne, B., Cecchini, G. and Iwata, S. (2003) Architecture of succinate dehydrogenase and reactive oxygen species generation. Science. 299, 700-704

\section{FOOTNOTES}

Abbreviations used: $\mathrm{O}_{2}$, oxygen; $\mathrm{Hb}$, hemoglobin; $\mathrm{AM}$, adrenal medulla; $\mathrm{TH}$, tyrosine hydroxylase; ROS, reactive oxygen species.

\section{FIGURE LEGENDS}

\section{Figure 1 Expression of $\alpha$-hemoglobin mRNA in the sympathoadrenal cells}

(A) Flow-cytometry sorting of cells dissociated from the adrenal medulla (AM, top panels) and the superior cervical ganglion (SCG, bottom panels) of TH-EGFP mice. Left panels show a sample of fluorescent (gray) cells. Middle panels shown bright field images. Right panels show the sorted (R3) and the negative (R11) cell populations from AM (top) or SCG (bottom) cultures. (B) Standard RTPCR showing $\alpha$-hemoglobin $(\alpha-\mathrm{Hb}, H b a-a 2)$ and not $\beta$-hemoglobin $(\beta-H b, H b b-b 1)$ expression in $\mathrm{TH}+(\mathrm{R} 3$ in $A)$ cells sorted from AM and SCG. "Other" represents the cells from R11 in A. (C) $\alpha-\mathrm{Hb}$ mRNA expression detected in PC12 cells by RT-PCR. (D) Analysis of expression of $\alpha$ - and $B-H b$ mRNAs in NIH-3T3 and MAH cell lines. In $B-D$, an erythroid lineage specific gene (Alas2) was amplified as a control and the amount of RNA used in each experiment was verified with the amplification of a housekeeping gene (Ppia). C-indicates a non-cDNA PCR and $\mathrm{C}+$ a sample with high blood content (mRNA extracted from rat heart).

Figure 2 PC12 clones overexpressing Wt- $\alpha-\mathrm{Hb}$ or Mut- $\alpha-\mathrm{Hb}$ 
(A) Schematic representation of the constructions used for over-expressing wild type (Wt- $\alpha-\mathrm{Hb}$ ) and mutated (Mut- $\alpha-\mathrm{Hb}) \alpha-\mathrm{Hb}$ forms in PC12 cells. An IRES sequence was used to express Eraf gene in the same cells. Blacks lines represent the CMV-ß-act promoter, light gray lines the Hba-a2 gene, black loop the IRES, and dark gray lines the Eraf gene. (B) qRT-PCR analysis of the relative Hba-a2 (light gray) or Eraf (dark gray) mRNA levels. Data (relative to PC12) are represented as mean \pm standard error of the mean (S.E.M.); $(n=5 ; * p<0.05)$.

\section{Figure 3 Modulation of oxygen-regulated genes by $\alpha$-Hb overexpression}

(A) qRT-PCR analysis of the normoxic levels of Vegfa (left panel) and Th (right panel) mRNAs in several $\alpha-\mathrm{Hb}$ expressing PC12 cells. Black bars represent PC12, dark gray bars Mut- $\alpha-\mathrm{Hb}$, and light gray bars Wt- $\alpha-\mathrm{Hb}$ cells. (B) Relative levels of Vegfa (left panel) and Th (right panel) mRNA in PC12, Mut- $\alpha-\mathrm{Hb}$, and $\mathrm{Wt}-\alpha-\mathrm{Hb}$ cells subjected to normoxia (gray bars) or hypoxia (dark bars: $1 \% \mathrm{O}_{2}$ ) for 24 h. Data, relative to PC12, are represented as mean \pm standard error of the mean (S.E.M.); $(n=$ $3 ; * p<0.05)$.

Figure 4. Modulation of oxidative defenses by $\alpha-\mathrm{Hb}$ overexpression

qRT-PCR analysis of the normoxic levels of Gpxl (left panel), Sod1 (middle panel), and Cat (right panel) mRNAs in several $\alpha-\mathrm{Hb}$ expressing PC12 cells. Black bars represent PC12, dark gray bars Mut- $\alpha-\mathrm{Hb}$, and light gray bars Wt- $\alpha-\mathrm{Hb}$ cells. Data, relative to PC12, are represented as mean \pm standard error of the mean (S.E.M.); $(n=3 ; * p<0.05)$.

\section{Figure 5 Proteomic analysis of $\alpha-\mathrm{Hb}$ over-expressing cells}

(A-B) 2-DE maps of a PC12 subcellular fraction. A Representative image of 2-DE is shown for soluble (A, S100 fraction) and mitochondrial (B, P15 fraction) subcellular fraction. Encircled spots present differential expression in Wt- $\alpha-\mathrm{Hb}$ cells when compared with extracts isolated from PC12 and Mut- $\alpha-\mathrm{Hb}$ cells. Numbers correspond with Supplemental Table 2.

\section{Figure $6 \alpha$-Hb overexpression enhances PC12 catecholaminergic phenotype}

(A) Western blot analysis of the TH protein levels in PC12, Mut- $\alpha-\mathrm{Hb}$, and $\mathrm{Wt}-\alpha-\mathrm{Hb}$ cells. Upper panels show a representative western blot image. Ribosomal protein RPL26 is shown as a loading control. Bottom panel shows the quantification of three independent western blots. (B) HPLC determination of the rate of synthesis of L-DOPA in PC12, Mut- $\alpha-\mathrm{Hb}$, and Wt- $\alpha-\mathrm{Hb}$ cells. Results are shown as relative to PC12 control cells. (C) HPLC determination of the absolute levels of dopamine (left panel) and noradrenaline (right panel) in PC12 and $\mathrm{Wt}-\alpha-\mathrm{Hb}$ cells. Data are represented as mean \pm standard error of the mean (S.E.M.); $(n=3 ; * p<0.05 ; * * p<0.01)$.

Figure 7 Schematic representation of the main pathways affected by $\alpha-\mathrm{Hb}$ overexpression

Left panel, $\alpha-\mathrm{Hb}$ expression and basal metabolic reactions affecting lipid metabolism and Krebs cycle in PC12 cells. Right panel, $\alpha-\mathrm{Hb}$ overexpression is associated with an optimization of the antioxidant defenses (1); a reorganization of lipid metabolism (2); and an increase in TH mRNA and protein levels (3). DA: dopamine; NA: noradrenaline. Metabolic pathways accelerated $(>)$ or slow down $(<)$ by $\alpha-\mathrm{Hb}$ overexpression are shown. Metabolites expected to change by $\alpha-\mathrm{Hb}$ expression are shown with a different font size. 

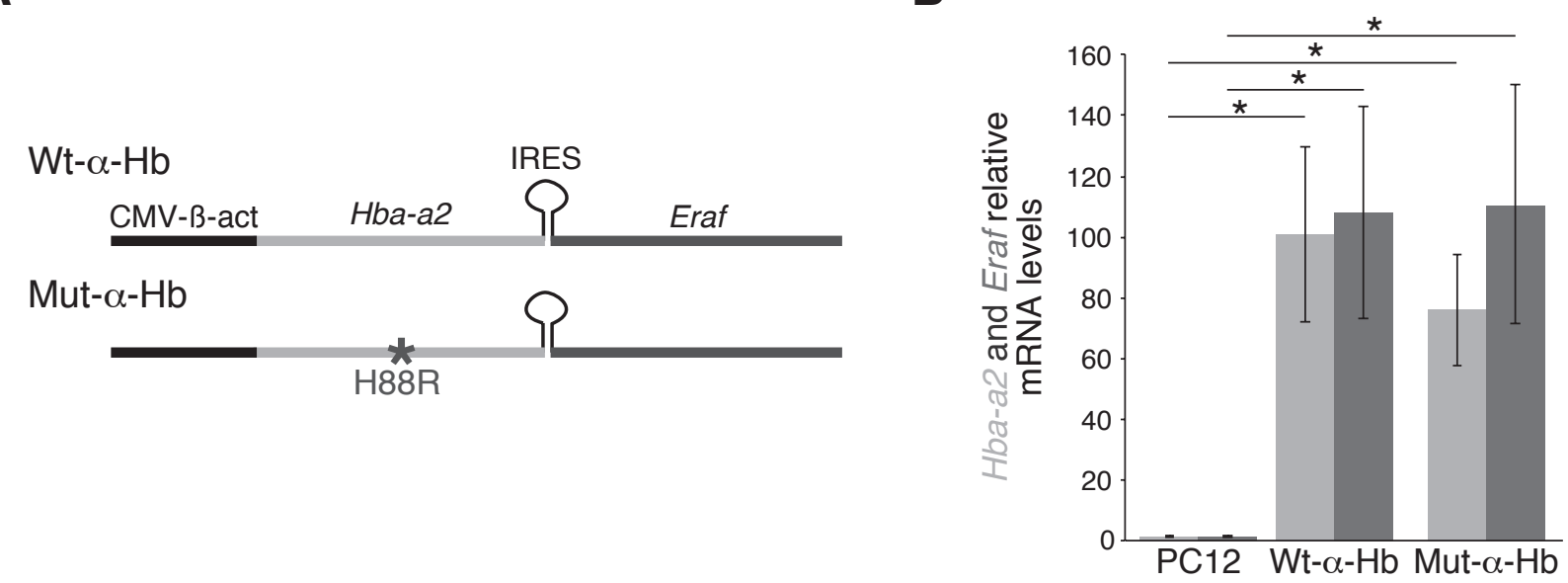

Marcos-Almaraz et al. Figure 2 

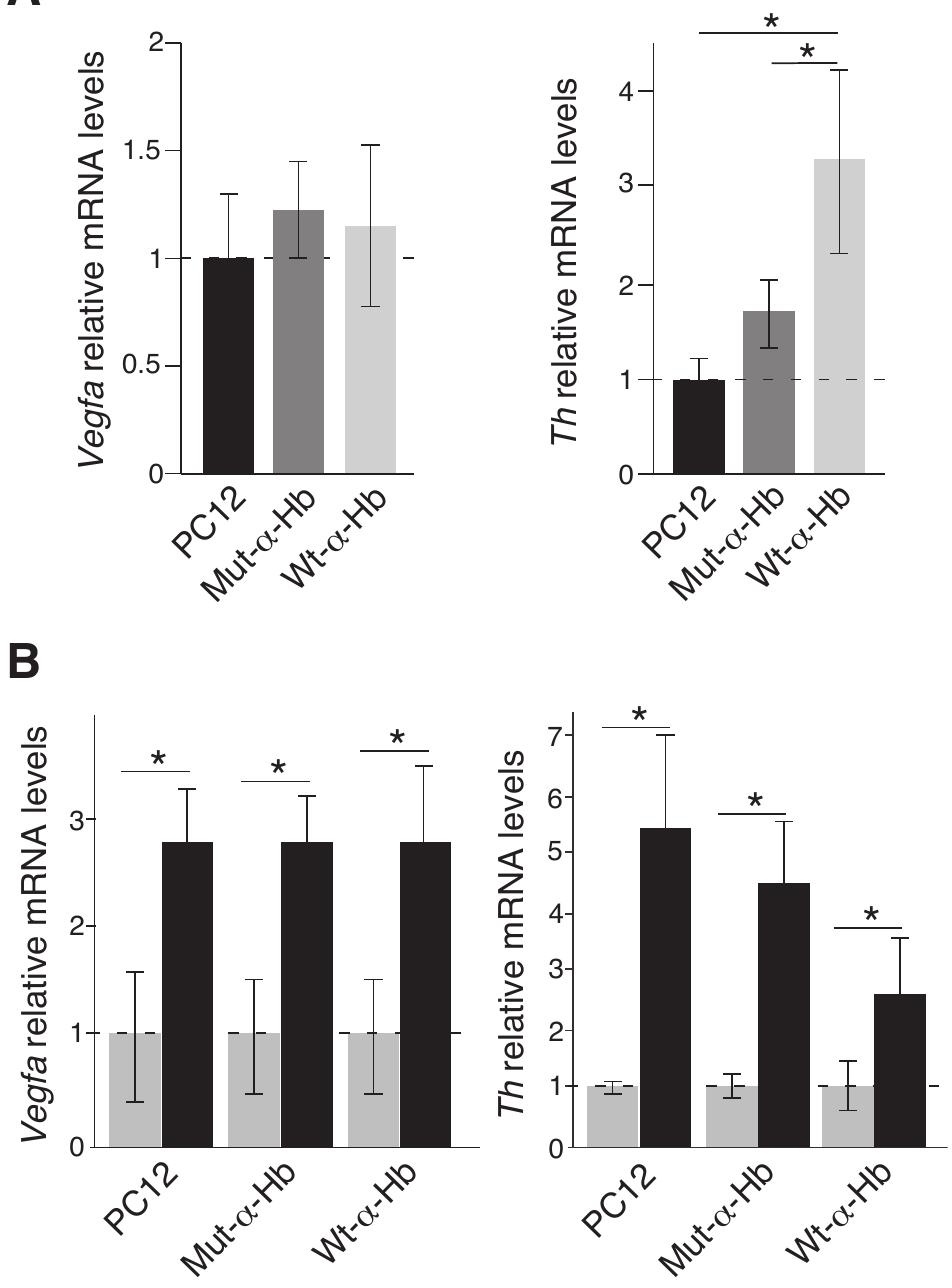

Marcos-Almaraz et al. Figure 3 

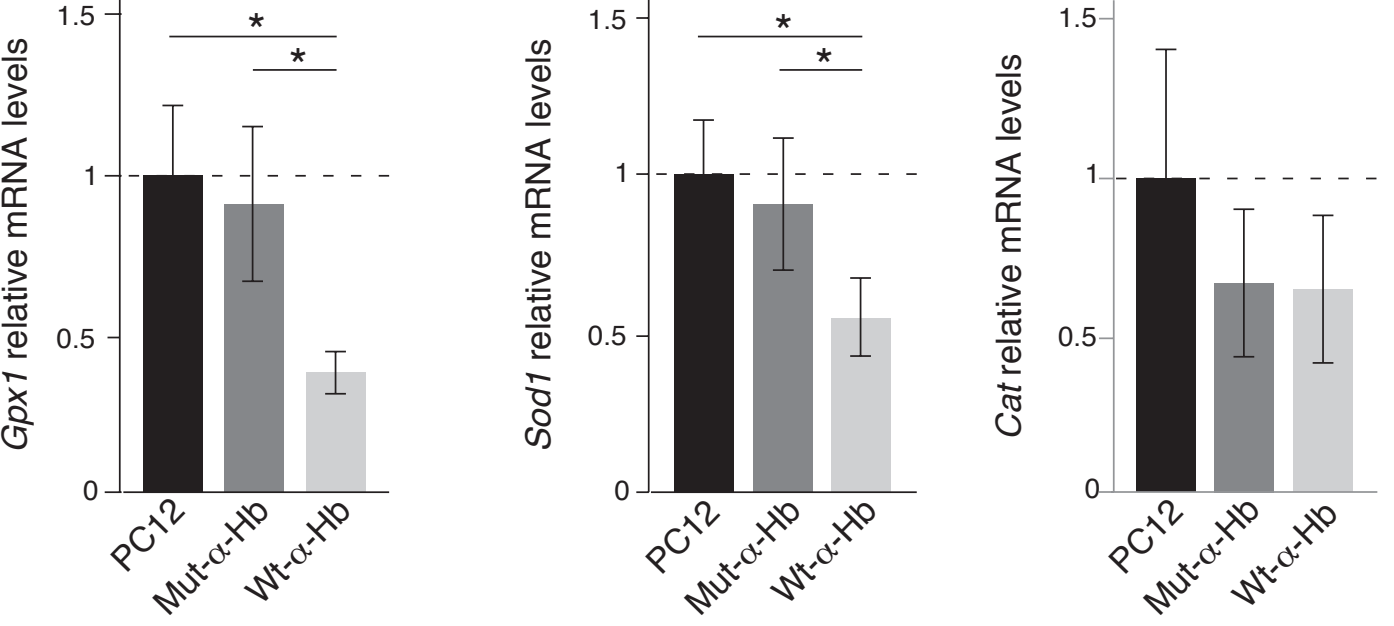

Marcos-Almaraz et al. Figure 4 
A Soluble (S100) fraction

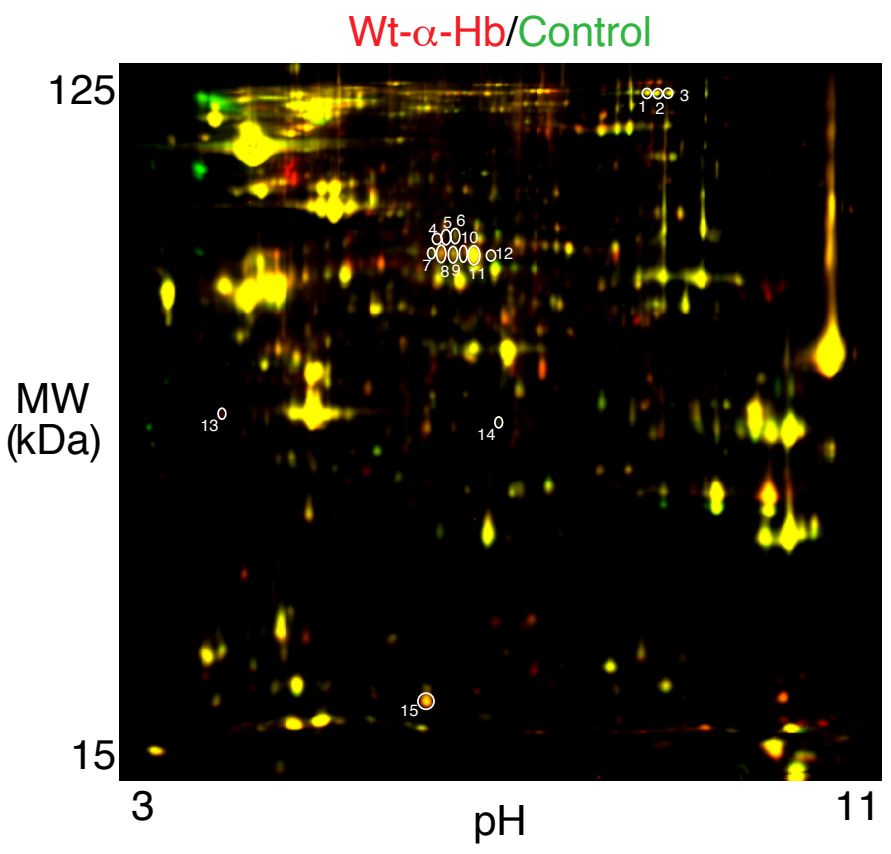

B

Mitochondrial (P15) fraction

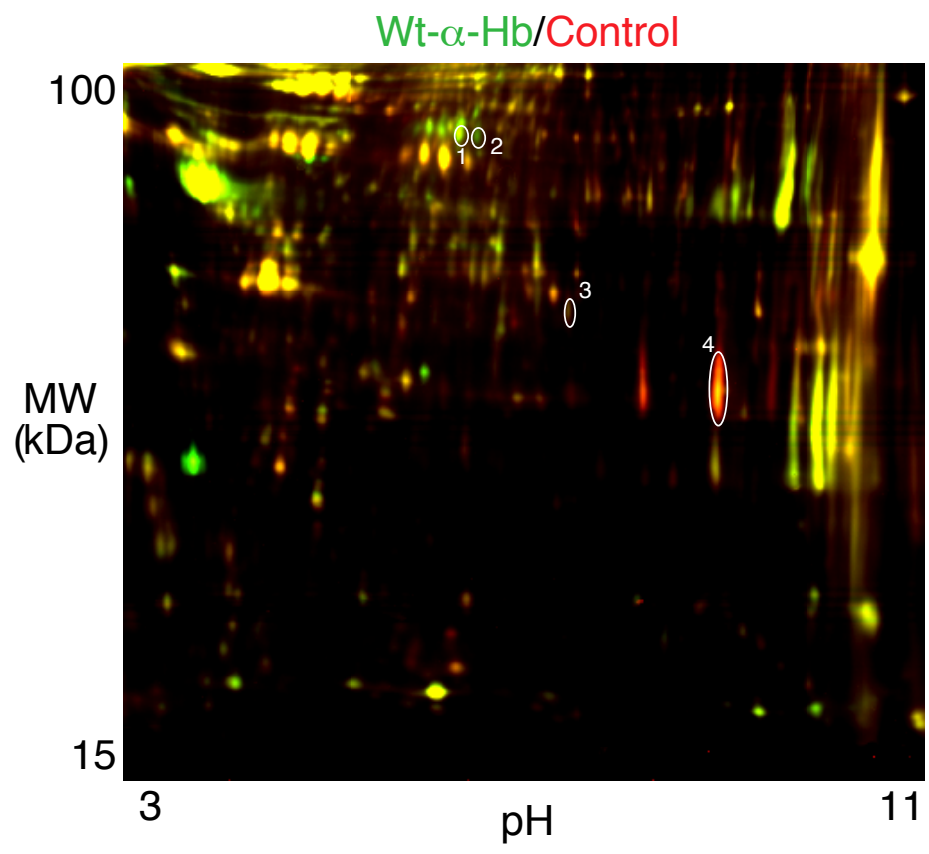

Marcos-Almaraz et al. Figure 5 


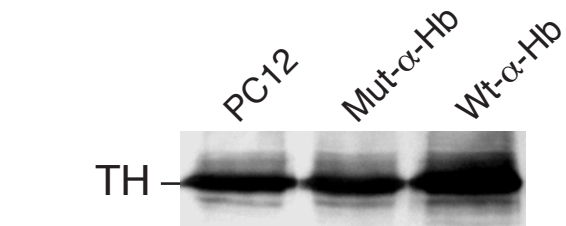

RPL26 -

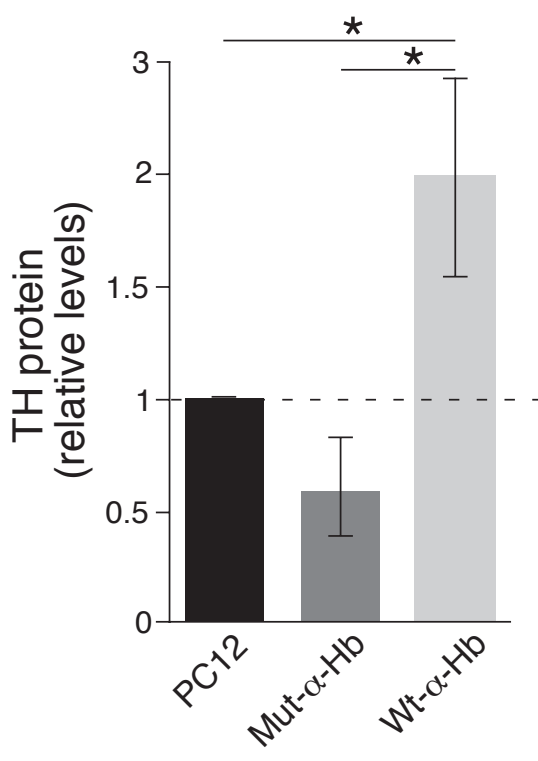

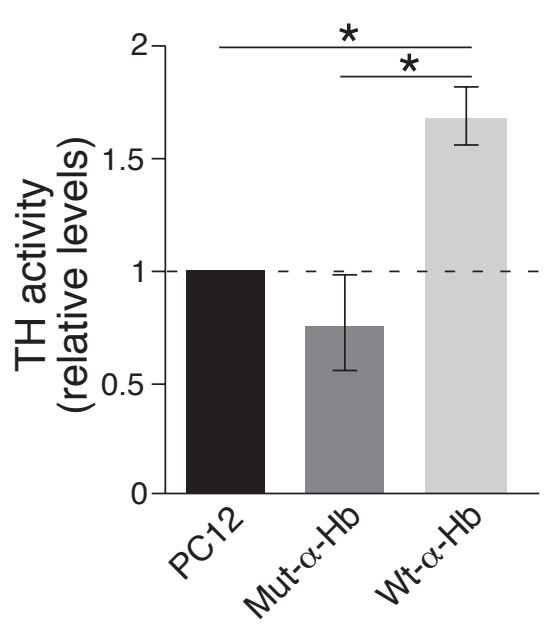
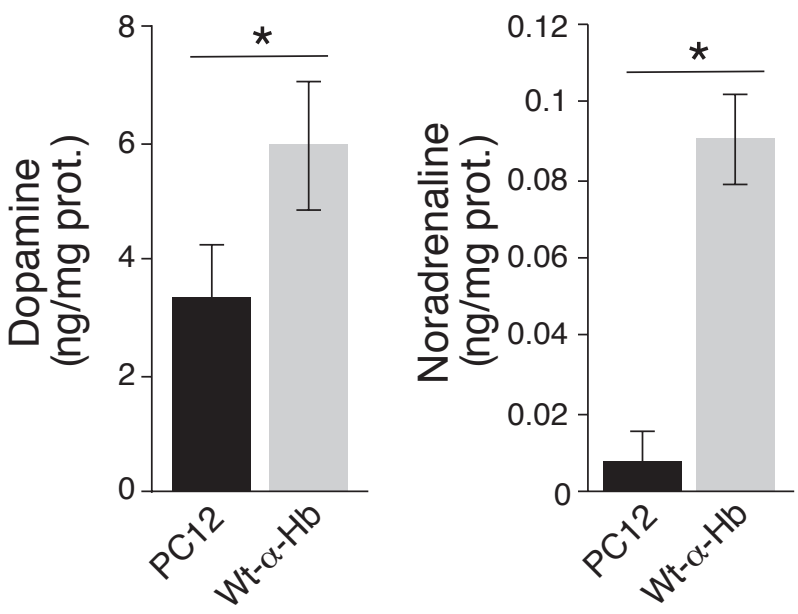

Marcos-Almaraz et al. Figure 6 


\section{ALPHA-HEMOGLOBIN REGULATES SYMPATHOADRENAL CELL METABOLISM TO MAINTAIN CATECHOLAMINERGIC PHENOTYPE}

María T. Marcos-Almaraz , José A. Rodríguez-Gómez ${ }^{*}$, José López-Barneo ${ }^{*}$, , and Alberto Pascual ${ }^{*}, \dagger$.

From Instituto de Biomedicina de Sevilla, Hospital Universitario Virgen del Rocío/ CSIC/Universidad de Sevilla, 41013 Seville, Spain", and Centro de Investigación Biomédica en Red sobre Enfermedades Neurodegenerativas (CIBERNED), Spain ${ }^{\dagger}$.

Short title: $\alpha-\mathrm{Hb}$ expression in sympathoadrenal lineage

\section{Supplemental data}




\begin{tabular}{|l|c|}
\hline Gene (denomination) & PC12 expression \\
\hline Hba-a2 (Hemoglobin alpha, adult chain 2) & Yes \\
\hline Hbb-b1 (Hemoglobin beta, major form) & No \\
\hline LOC100134871 (Hemoglobin beta, minor form) & No \\
\hline Hbe1_predicted (Hemoglobin Epsilon 1) & No \\
\hline Hbe2_predicted (Hemoglobin Epsilon 2) & No \\
\hline Hbg 1 (Hemoglobin Gamma 1) & No \\
\hline Hbq1 (Hemoglobina Theta) & No \\
\hline Hbz (Hemoglobina Zeta) & No \\
\hline
\end{tabular}

Supplemental Table 1 Study of the Hb chains expressed by PC12 cells 
Supplemental Table 2 Proteins modulated by wt- $\alpha-\mathrm{Hb}$ overexpression and identified by MALDI-MS/MS analysis

\begin{tabular}{|c|c|c|c|c|c|c|c|c|c|c|c|}
\hline \multicolumn{8}{|l|}{$\mathbf{S 1 0 0}$} & \multicolumn{2}{|c|}{ Wt vs Control } & \multicolumn{2}{|c|}{ Wt vs Mut } \\
\hline $\begin{array}{c}\text { Spot } \\
\text { number }\end{array}$ & $\begin{array}{c}\text { Mascot } \\
\text { score }\end{array}$ & $\begin{array}{l}\text { Protein } \\
\text { C.I. } \%{ }^{1}\end{array}$ & Protein name (gene name) & $\begin{array}{c}\text { Peptide } \\
\text { count }\end{array}$ & $\begin{array}{c}\text { Total } \\
\text { ion } \\
\text { score }\end{array}$ & $\begin{array}{l}\text { Ion } \\
\text { C.I. } \\
\%{ }^{1}\end{array}$ & $\begin{array}{c}\text { Accession } \\
\text { number }\end{array}$ & $t$-test value & $\begin{array}{c}\text { Average } \\
\text { ratio }\end{array}$ & $\begin{array}{l}t \text {-test } \\
\text { value }\end{array}$ & $\begin{array}{c}\text { Average } \\
\text { ratio }\end{array}$ \\
\hline 1 & 220 & 100 & ATP citrate lyase isoform $1($ Acly $)$ & 25 & 79 & 100 & EDM06044 & 0.007075 & -1.662 & 0.001698 & -2.287 \\
\hline 2 & 841 & 100 & ATP citrate lyase isoform 1 (Acly) & 26 & 115 & 100 & EDM06044 & 0.006287 & -1.861 & 0.000829 & -2.359 \\
\hline 3 & 417 & 100 & ATP citrate lyase isoform 1 (Acly) & 32 & 194 & 100 & EDM06044 & 0.000443 & -1.814 & 0.000173 & -2.371 \\
\hline 4 & 245 & 100 & Tyrosine hydroxylase $(T h)$ & 14 & 155 & 100 & EDM12167 & 0.001328 & 1.847 & 0.007826 & 1.837 \\
\hline 5 & 527 & 100 & Tyrosine hydroxylase $(T h)$ & 17 & 400 & 100 & EDM12167 & 0.003329 & 2.287 & 0.031230 & 1.939 \\
\hline 6 & 582 & 100 & Tyrosine hydroxylase $(T h)$ & 19 & 432 & 100 & EDM12167 & 0.002614 & 1.818 & 0.026600 & 1.600 \\
\hline 7 & 747 & 100 & Tyrosine hydroxylase $(T h)$ & 20 & 565 & 100 & EDM12167 & 0.003126 & 1.962 & 0.003657 & 1.922 \\
\hline 8 & 850 & 100 & Tyrosine hydroxylase $(T h)$ & 23 & 646 & 100 & EDM12167 & 0.000127 & 2.415 & 0.001582 & 2.166 \\
\hline 9 & 863 & 100 & Tyrosine hydroxylase $(T h)$ & 21 & 682 & 100 & EDM12167 & 0.002391 & 3.088 & 0.012970 & 2.582 \\
\hline 10 & 952 & 100 & Tyrosine hydroxylase $(T h)$ & 18 & 808 & 100 & EDM12167 & 0.004938 & 2.119 & 0.036420 & 1.762 \\
\hline 11 & 1400 & 100 & Tyrosine hydroxylase $(T h)$ & 24 & 1169 & 100 & EDM12167 & 0.008190 & 2.884 & 0.033340 & 2.253 \\
\hline 12 & 701 & 100 & Dihydropyrimidinase-like 3 & 22 & 524 & 100 & EDM02978 & 0.000009 & 2.538 & 0.006196 & 1.827 \\
\hline 13 & 324 & 100 & Keratin $18($ Krt18) & 14 & 233 & 100 & NP_446428.1 & 0.007656 & 2.250 & 0.028540 & 1.962 \\
\hline 14 & 574 & 100 & Aminoacylase $1(A c y l)$ & 20 & 383 & 100 & NP_001005383.1 & 0.000231 & 1.752 & 0.001111 & 1.574 \\
\hline 15 & 713 & 100 & Peroxiredoxin $6(\operatorname{Prdx} \sigma)$ & 14 & 575 & 100 & CAA76732 & 0.001635 & 1.512 & 0.000024 & 2.586 \\
\hline \multicolumn{8}{|l|}{ P15 } & \multicolumn{2}{|c|}{ Wt vs Control } & \multicolumn{2}{|c|}{ Wt vs Mut } \\
\hline $\begin{array}{c}\text { Spot } \\
\text { number }\end{array}$ & $\begin{array}{l}\text { Protein } \\
\text { score }\end{array}$ & $\begin{array}{l}\text { Protein } \\
\text { C.I. } \%{ }^{1}\end{array}$ & Protein name (gene name) & $\begin{array}{l}\text { Peptide } \\
\text { count }\end{array}$ & $\begin{array}{c}\text { Total } \\
\text { ion } \\
\text { score }\end{array}$ & $\begin{array}{c}\text { Ion } \\
\text { C.I. \% }\end{array}$ & $\begin{array}{c}\text { Accession } \\
\text { number }\end{array}$ & $t$-test value & $\begin{array}{c}\text { Average } \\
\text { ratio }\end{array}$ & $\begin{array}{l}t \text {-test } \\
\text { value }\end{array}$ & $\begin{array}{c}\text { Average } \\
\text { ratio }\end{array}$ \\
\hline 1 & 535 & 100 & Tyrosine hydroxylase $(T h)$ & 19 & 376 & 100 & EDM12167 & 0.042820 & 2.144 & 0.020370 & 2.181 \\
\hline 2 & 1100 & 100 & Tyrosine hydroxylase $(T h)$ & 29 & 806 & 100 & EDM12167 & 0.016650 & 2.214 & 0.004986 & 2.535 \\
\hline 3 & 255 & 100 & Long-chain acyl-CoA dehydrogenase precursor $(A c a d l)$ & 12 & 188 & 100 & NP_036951.1 & 0.006522 & 1.653 & 0.013830 & 1.506 \\
\hline 4 & 548 & 100 & Annexin A2 (Anxa2) & 18 & 406 & 100 & NP_063970.1 & 0.000296 & -2.615 & 0.005998 & -1.562 \\
\hline
\end{tabular}

Positive values indicate proteins with a greater abundance in wt- $\alpha-H b$ clones. Negative values represent decreased abundance in the same clones. ${ }^{1}$ : C.I. Confidential Index (\%). 